\title{
Child Neurology: Triosephosphate isomerase deficiency
}

Corrie Harris, MD, Bailey Nelson, MD, Darren Farber, MD, Scott Bickel, MD, Heather Huxol, MD, Alexander Asamoah, MD, PhD, and Ronald Morton, MD

Neurology ${ }^{\circledR}$ 2020;95:e3448-e3451. doi:10.1212/WNL.0000000000010745

Triosephosphate isomerase (TPI) deficiency is a rare autosomal recessive disease of infancy and childhood classified as a glycolytic enzymopathy. Clinical features include hemolytic anemia, progressive neuromuscular dysfunction, and increased susceptibility to infection with specific pathogenic variants resulting in severe disease and death by age 8 . Since initially described in 1965, ${ }^{1}$ fewer than 50 clinically affected patients have been described in the literature. We describe a 20-year-old patient with a severe pathogenic variant in the TPI gene who has outlived all reported cases, residing in a long-term care facility for most of her life with aggressive medical interventions.

\section{Clinical case}

The proband was born at term after an uncomplicated pregnancy to a gravida 1 mother. Her birthweight was 3,409 g. She was diagnosed with hepatomegaly, nonspherocytic hemolytic anemia, and jaundice that required phototherapy in the neonatal intensive care unit. She experienced her first hemolytic crisis requiring blood transfusion at 4 months of age. Bone marrow biopsy at 5 months of age was consistent with congenital dyserythropoietic anemia. Her growth and development were normal. At age 13 months, she was hospitalized with pneumonia and respiratory failure that required intubation. Developmental motor delay was noted, which worsened during her acute illness. Multiple failed trials at extubation resulted in tracheostomy placement. Physical examination during this admission revealed an alert interactive child who could reach for and grasp objects and sit without assistance, but could not pull to a stand (figure 1A). Diffuse muscle weakness and increased tone was noted in all extremities, lower greater than upper, with normal deep tendon reflexes. Initial laboratory evaluations including complete blood count, comprehensive metabolic panel, thyroid studies, serum creatine phosphokinase level, botulinum toxin, carnitine, and CSF analysis were normal. Blood, urine, and CSF cultures were negative for infection. Brain and spine MRI were normal. Evaluation for a primary neuromuscular disorder was negative, including normal EMG and nerve conduction studies, muscle biopsy, Tensilon test, and DMPK trinucleotide repeat testing for congenital myotonic dystrophy. Our patient remained ventilatordependent, and experienced slow progression of motor weakness and developmental delay. At age 4 years, her physical examination revealed macrocephaly, bifacial weakness including ptosis, nystagmus, and upper and lower extremity spasticity. Diffuse progressive muscle weakness with proximal muscles more severely affected, brisk upper and absent lower extremity deep tendon reflexes, and an action tremor of the upper extremities were noted. Additional evaluation including SMA gene testing, urine organic and plasma amino acid analyses, Canavan disease, Kennedy disease, and lysosomal storage diseases enzyme testing was negative. Repeat brain MRI was normal except frontal bossing and macrocrania were noted due to extramedullary hematopoiesis. At 20 years of age, our patient has developed quadriparesis with generalized hypotonia, muscle atrophy, loss of deep tendon reflexes of upper and lower extremities, and uses a wheelchair for mobility (figure 1, D and E). Progressive facial weakness has resulted in dysarthria, dysphagia, and tongue fasciculations. She experiences chronic mild hemolysis exacerbated by acute illness. Physical disease

\author{
Correspondence \\ Dr. Harris \\ Corrie.Harris@Louisville.edu
}

\footnotetext{
From the Divisions of Pediatric Hospitalist Medicine (C.H., H.H.), Pediatric Neurology (D.F.), Pediatric Pulmonology (S.B., R.M.), and Pediatric Genetics (A.A.), University of Louisville School of Medicine (B.N.), KY.

Go to Neurology.org/N for full disclosures. Funding information and disclosures deemed relevant by the authors, if any, are provided at the end of the article.
} 


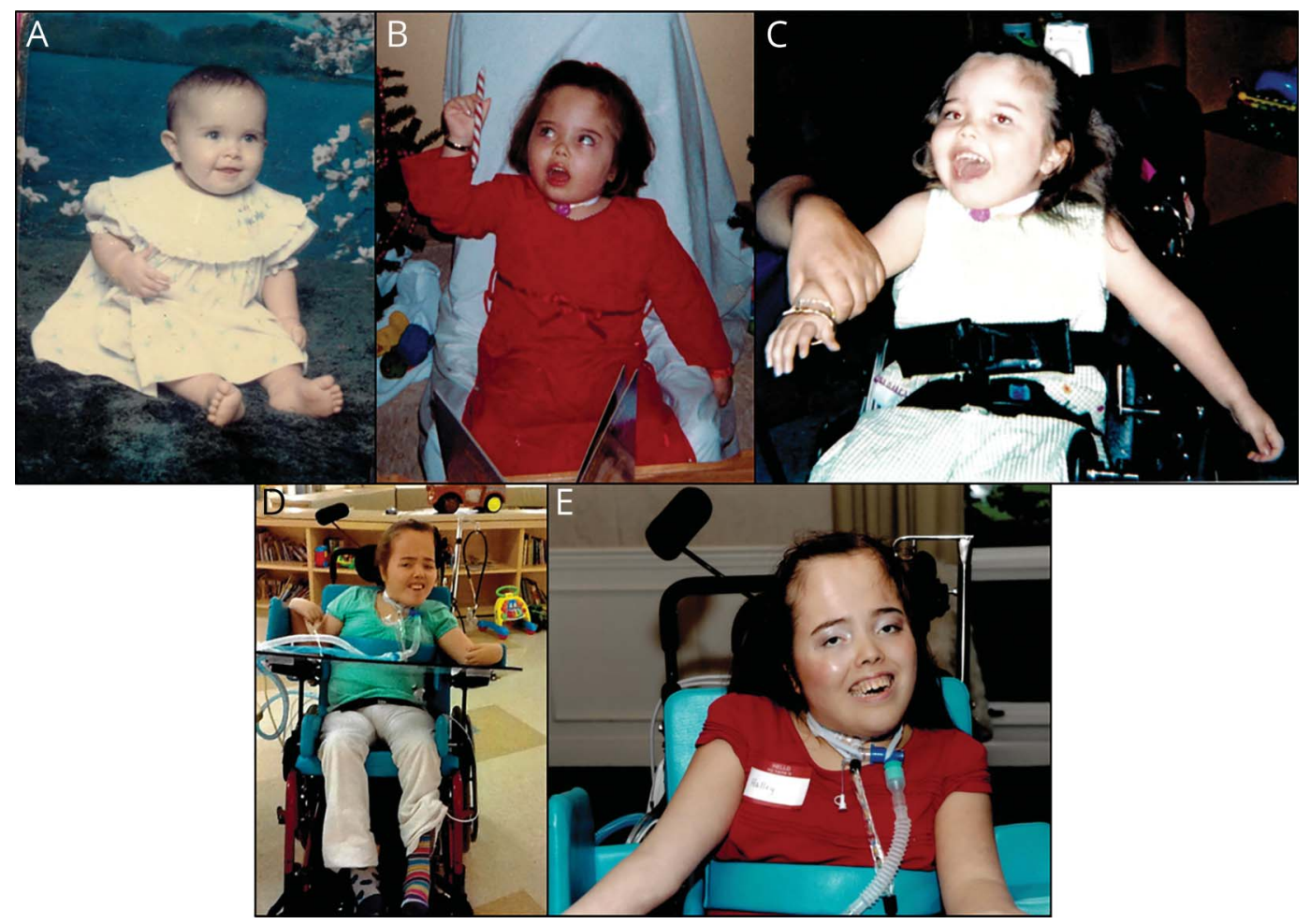

(A) At age 12 months, the child sits without support, cannot pull to a stand, and increased tone in lower extremities is noted. (B, C) At age 3 years, the child is ventilator- and wheelchair-dependent with progressive muscle weakness involving proximal muscles preferentially. (D, E) At age 12-18 years, the child remains interactive with quadriparesis, diffuse hypotonia, bilateral facial weakness, muscle wasting of all extremities, and contractures of upper extremities. Note macrocephaly secondary to extramedullary hematopoiesis.

manifestations have exceeded intellectual impairment, with a diagnosis of moderate intellectual disability at age 19. The patient has 2 unaffected siblings, a healthy brother and sister.

NextGen sequencing for congenital dyserythropoietic anemia panel comprising the genes CDAN1, GATA1, KIF23, KLF1, and SEC23B was normal. Blood for hemolytic red blood cell panel done at 15 years of age showed triose phosphate isomerase deficiency. Blood for Sanger sequencing performed in a commercial laboratory showed that the patient is homozygous for the most common variant p.Glu105Asp (c.315G $>$ C) that was previously described as p.Glu104Asp associated with TPI deficiency (figure 2).

\section{Discussion}

TPI deficiency is a rare autosomal recessive multisystem genetic disorder characterized by non-spherocytic hemolytic anemia that begins from birth and over time progresses to neuromuscular dysfunction, increased susceptibility to infections, cardiomyopathy, respiratory failure, and ultimately death in early childhood. Our patient survived respiratory failure at age 13 months with chronic mechanical ventilatory support. The prevalence of TPI deficiency is unknown but fewer than 100 cases exist worldwide. TPI deficiency may also remain unrecognized, as TPI activity is not typically assayed in cases of hemolytic anemia.

Figure 2 Sequence change in the patient's TPI gene at codon 315 from G to C designated as c.315G > C (p.Glu105Asp)

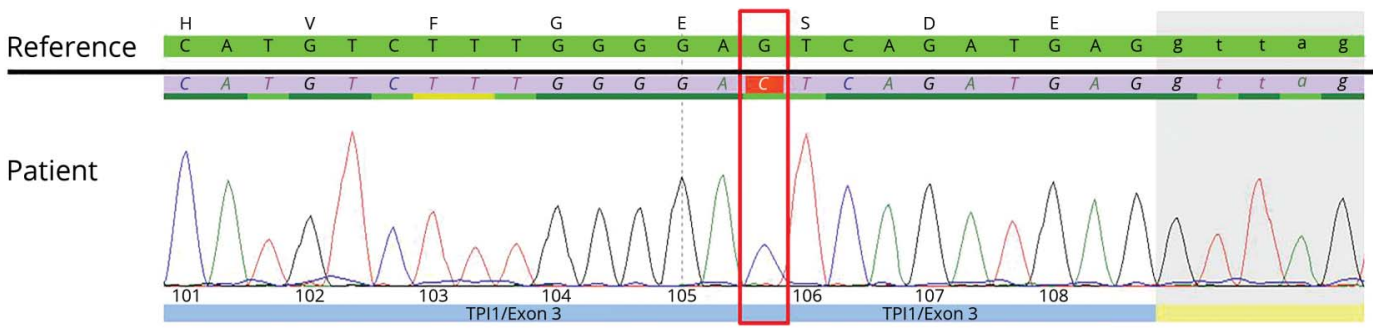




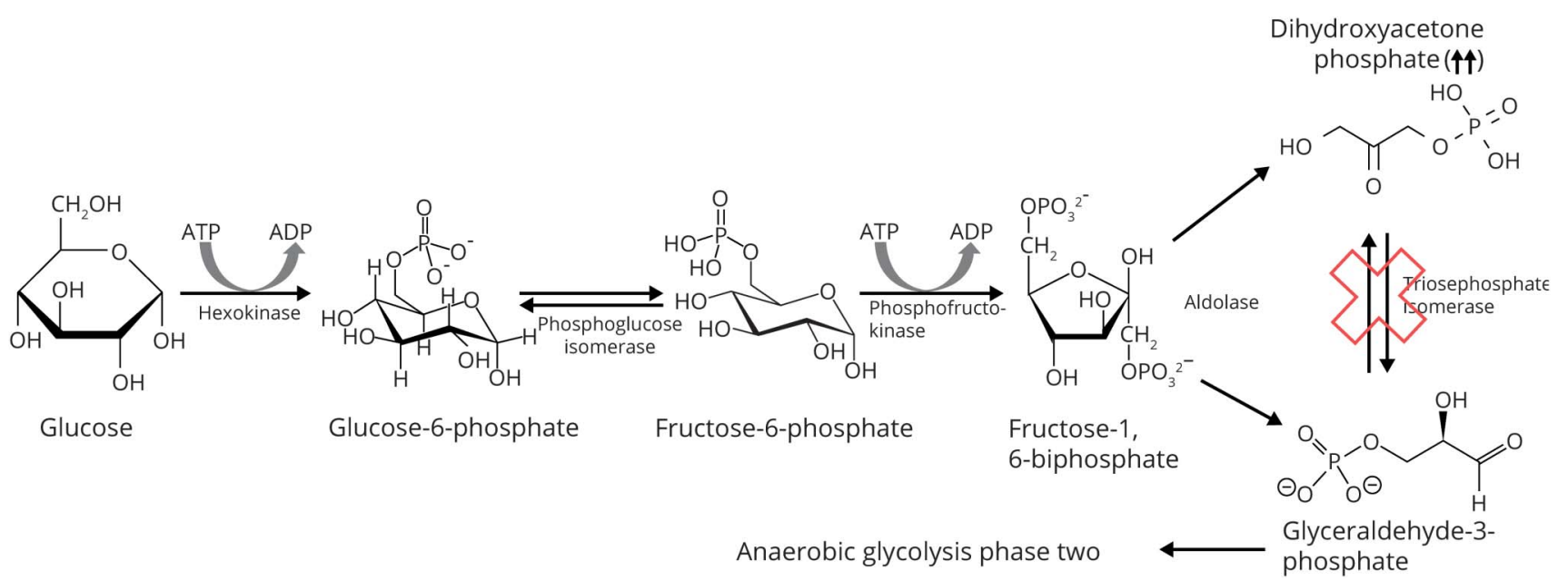

Triosephosphate isomerase (TPI) catalyzes the interconversion of glyceraldehyde-3-phosphate (GAP) and dihydroxyacetone phosphate (DHAP). TPI deficiency results in the accumulation of cellular DHAP and toxic biproducts. GAP available to enter the second phase of glycolysis is reduced, decreasing oxidative conversion of GAP to pyruvate and resultant ATP formation.

Clinical findings typically begin in infancy and include hemolytic anemia requiring blood transfusion. Progressive neurologic dysfunction becomes evident by 6-24 months of age, and rapid neurologic decline occurs with more significant disease in the legs, hypotonia, motor deficit, and loss of deep tendon reflexes. ${ }^{2}$ CNS involvement includes intellectual disability, epilepsy, dystonia, and dyskinesia. ${ }^{2}$ Patients typically experience increased susceptibility to infection, cardiomyopathy, and death in early childhood from infection or respiratory failure.

Numerous mutations in the gene coding for the TPI enzyme are known to result in TPI deficiency. The pathogenic variant, Glu105Asp substitution (previously described as p.Glu104Asp), is the most frequent, accounting for approximately $80 \%$ of clinical TPI cases. ${ }^{3,4}$ This variant causes the most severe symptoms, typically resulting in death in infancy or early childhood. ${ }^{5}$ Additional pathogenic variants have been identified, so far with infrequent occurrence, mostly in compound heterozygous form with Glu105Asp, and result in a less severe disease course. ${ }^{3,4}$

TPI is one of the enzymes in the glycolytic pathway. Glycolysis is the anaerobic metabolic process in which glucose is converted, through a series of steps, to pyruvic acid, during which energy is released in the form of ATP in cells. Red blood cells lack mitochondria and are therefore dependent on this anaerobic process to create ATP. Defects in any of the enzymes in the glycolytic pathway result in bioenergetic deficiency and chronic hemolytic anemia. However, defects of only 3 of the glycolytic enzymes (TPI, phosphoglycerate kinase, and glucose-6-phosphate isomerase) are associated with neurologic manifestations. TPI deficiency is the most rare and results in disease more severe than any other glycolytic enzyme deficiency. ${ }^{4}$ TPI catalyzes the interconversion of glyceraldehyde 3-phosphate (GAP) and dihydroxyacetone phosphate (DHAP) (figure 3). A deficiency in TPI results in accumulation of the substrate DHAP. Accumulated DHAP may decompose to form advanced glycation end products that are toxic to cells in large concentrations. ${ }^{6}$ Also, TPI is catalytically active only in its dimeric form. ${ }^{4}$ Evidence suggests that reduction in the stability of the dimeric enzyme due to TPI pathogenic variants and thermoliability may be a crucial component in the etiology of illness. ${ }^{4}$ Mutant TPI protein may misfold, resulting in toxic protein aggregates that trigger neurologic dysfunction. ${ }^{6}$ These pathogenic mechanisms may contribute to neurodegeneration in addition to decreased red cell survival. ${ }^{6}$

Treatment of patients with TPI deficiency is supportive, but enzyme replacement therapy and cord blood transplantation may offer hope for children diagnosed early in infancy. ${ }^{7}$

Homozygotes of the Glu105Asp variant, as in our patient, tend to exhibit the most severe symptoms, resulting in death in infancy or early childhood. ${ }^{4}$ To date, only 2 patients have been described in the literature homozygous for this mutation who lived past age 2 years; 1 alive at 5 years and 1 at 8 years of age. ${ }^{8,9}$ TPI deficiency is autosomal recessive, but it is possible that there are modifier genes yet to be identified and environmental factors that interact with the TPI pathogenic variants that have influenced the course of disease in our patient. Aggressive supportive care including mechanical ventilator support, physical, occupational, and speech therapies, and aggressive management of infections and anemia starting at an early age in a chronic care facility may have helped slow down the rapid neurologic regression that has been described in previous cases. She uses a wheelchair and 
is ventilator-dependent, but at age 20 our patient continues to have meaningful interactions with care facility staff and her family.

\section{Disclosure}

The authors report no disclosures relevant to the manuscript. Go to Neurology.org/N for full disclosures.

\section{Acknowledgment}

The authors thank Luke Drury, Laboratory Directory, PreventionGenetics, Marshfield, Wisconsin, for providing Sanger sequencing data; and the patient, parents, and facility staff for their cooperation.

\section{Study funding}

No targeted funding reported.

\section{Appendix Authors}

\begin{tabular}{lll}
\hline Name & Location & Contribution \\
\hline $\begin{array}{l}\text { Corrie Harris, } \\
\text { MD }\end{array}$ & $\begin{array}{l}\text { University of } \\
\text { Louisville, KY }\end{array}$ & $\begin{array}{l}\text { Acquisition of information, drafting } \\
\text { and revising the manuscript }\end{array}$ \\
\hline $\begin{array}{l}\text { Bailey Nelson, } \\
\text { MD }\end{array}$ & $\begin{array}{l}\text { University of } \\
\text { Louisville, KY }\end{array}$ & $\begin{array}{l}\text { Conceptualized paper, acquisition of } \\
\text { information, drafting the initial } \\
\text { manuscript }\end{array}$ \\
\hline $\begin{array}{l}\text { Darren Farber, } \\
\text { MD }\end{array}$ & $\begin{array}{l}\text { University of } \\
\text { Louisville, KY }\end{array}$ & $\begin{array}{l}\text { Revising the manuscript for } \\
\text { intellectual content }\end{array}$ \\
\hline
\end{tabular}

Appendix (continued)

\begin{tabular}{lll}
\hline Name & Location & Contribution \\
\hline $\begin{array}{l}\text { Scott Bickel, } \\
\text { MD }\end{array}$ & $\begin{array}{l}\text { University of } \\
\text { Louisville, KY }\end{array}$ & $\begin{array}{l}\text { Drafting figures, technical support, } \\
\text { revising manuscript for intellectual } \\
\text { content and format }\end{array}$ \\
\hline $\begin{array}{l}\text { Heather Huxol, } \\
\text { MD }\end{array}$ & $\begin{array}{l}\text { University of } \\
\text { Louisville, KY }\end{array}$ & $\begin{array}{l}\text { Revising the manuscript for } \\
\text { intellectual content }\end{array}$ \\
$\begin{array}{l}\text { Alexander } \\
\text { Asamoah, MD, } \\
\text { PhD }\end{array}$ & $\begin{array}{l}\text { University of } \\
\text { Louisville, KY }\end{array}$ & $\begin{array}{l}\text { Acquisition of information, revising } \\
\text { the manuscript for intellectual } \\
\text { content, provided substantial editing }\end{array}$ \\
\hline $\begin{array}{l}\text { Ronald } \\
\text { Morton, MD }\end{array}$ & $\begin{array}{l}\text { University of } \\
\text { Louisville, KY }\end{array}$ & $\begin{array}{l}\text { Revising the manuscript for } \\
\text { intellectual content }\end{array}$ \\
\hline
\end{tabular}

\section{References}

1. Schneider AS, Valentine WN, Hattori M, Heins HL. Hereditary hemolytic anemia with triose phosphate isomerase deficiency. N Engl J Med 1965;272:229-235.

2. Poll-The BT, Alcardi J, Girot R, Rosa R. Neurological findings in TPI deficiency. Ann Neurol 1985; 17:439-443.

3. Tanak KR, Zerez CR. Red cell enzymopathies of the glycolytic pathway. Semin Hematol 1990;27:165-185.

4. Orosz F, Olah J, Ovadi J. Triosephosphate isomerase deficiency: facts and doubts. IUBMB Life 2006;58:703-715.

5. Aissa K, Kamoun F, Sfaihi L, et al. Hemolytic anemia and progressive neurologic impairment: think about triosephosphate isomerase deficiency. Fetal Pediatr Pathol 2014;33:234-238.

6. Orosz F, Olah J, Ovadi J. Triosephosphate isomerase deficiency: new insights into an enigmatic disease. Biochim Biophys Acta 2009;1792:1168-1174.

7. Conway AJ, Brown FC, Hortle EJ, et al. Bone marrow transplantation corrects haemolytic anaemia in a novel ENU mutagenesis mouse model of TPI deficiency. Dis Model Mech 2018;11:dmm034678.

8. Linarello RE, Shetty AK, Thomas T, Warrier RP. Triosephosphate isomerase deficiency in a child with congenital hemolytic anemia and severe hypotonia. Pediatr Hematol Oncol 1998;15:533-536.

9. Wilmshurst JM, Wise GA, Pollard JD, Ourvrier RA. Chronic axonal neuropathy with triosephosphate isomerase deficiency. Pediatr Neurol 2004;30:146-148. 


\section{Neurology}

Child Neurology: Triosephosphate isomerase deficiency

Corrie Harris, Bailey Nelson, Darren Farber, et al.

Neurology 2020;95;e3448-e3451 Published Online before print September 1, 2020

DOI 10.1212/WNL.0000000000010745

This information is current as of September 1,2020

Updated Information \&

Services

References

Subspecialty Collections

Permissions \& Licensing

Reprints including high resolution figures, can be found at: http://n.neurology.org/content/95/24/e3448.full

This article cites 9 articles, 1 of which you can access for free at: http://n.neurology.org/content/95/24/e3448.full\#ref-list-1

This article, along with others on similar topics, appears in the following collection(s):

All Clinical Neurology

http://n.neurology.org/cgi/collection/all_clinical_neurology

All Neuromuscular Disease

http://n.neurology.org/cgi/collection/all_neuromuscular_disease

Hematologic

http://n.neurology.org/cgi/collection/hematologic

Metabolic disease (inherited)

http://n.neurology.org/cgi/collection/metabolic_disease_inherited

Information about reproducing this article in parts (figures,tables) or in its entirety can be found online at:

http://www.neurology.org/about/about_the_journal\#permissions

Information about ordering reprints can be found online:

http://n.neurology.org/subscribers/advertise

Neurology ${ }^{\circledR}$ is the official journal of the American Academy of Neurology. Published continuously since 1951, it is now a weekly with 48 issues per year. Copyright () 2020 American Academy of Neurology. All rights reserved. Print ISSN: 0028-3878. Online ISSN: 1526-632X.

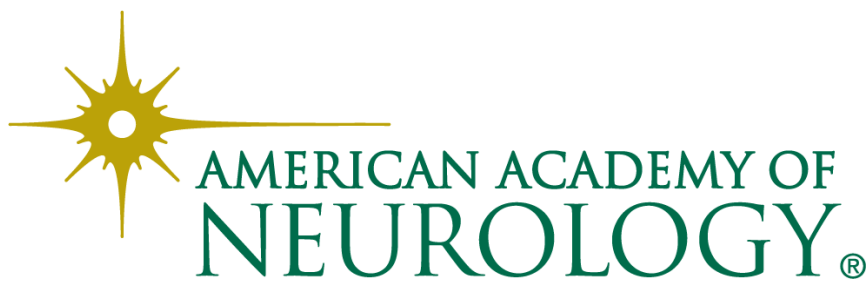

